\title{
Intravenous iron - personal experience of 1000 consecutive infusions
}

\author{
Esa Soppi* \\ Department of Internal medicine, Eira Hospital, Laivurinkatu 29, FI-00150 Helsinki, Finland
}

\begin{abstract}
Data on 1000 successive ferric carboxymaltose infusions involving 517 different individuals are presented. The infusions were safe and a clinically effective way of reconstituting the depleted iron stores in patients with iron deficiency anemia and with iron deficiency without anemia. The infusion was discontinued due to infusion-related adverse events in less than one percent of patients (5 out of 517). Some $60 \%$ of the patients required more than one infusion. Overall, some $80 \%$ of the patients achieved an excellent or good response. However, there seems to be no way of predicting the clinical response nor the need for further infusion(s). The median interval between infusions was about six months, but the variation of time between infusions was large. Thus, patients who require iron infusion therapy must be followed up for extended periods.
\end{abstract}

\section{Introduction}

Development of iron deficiency precedes the development of iron deficiency anemia and thus iron deficiency without anemia is at least twice as common as frank iron deficiency anemia [1]. Iron depletion has effects on several tissues and function, e.g., the skeletal muscle, the heart, brain and on the energy-producing machinery, and this can cause multiple symptoms [1-4]. Iron treatment should be started immediately when iron deficiency is detected, even in the absence of anemia, especially if the patient has symptoms $[5,6]$.

Oral iron salts are the mainstay of treating iron deficiency, but a considerable number of patients are intolerant, noncompliant or unresponsive to oral iron therapy, which jeopardizes the prolonged (several months) treatment required [1,7]. The alternative for these patients is intravenous administration of iron. This route of administration is gaining popularity since current intravenous iron products have a good safety profile $[8,9]$. The advantages of intravenous administration over oral administration are rapid reconstitution of iron stores and the negligible gastrointestinal toxicity [1]. Currently, highdose schedules are considered convenient since the clinical effect is rapid and the number of hospital visits is kept low [1]. However, the decisions on dose should be made carefully on an individual basis.

Here I report my clinical experience and results from 1000 successive infusions of ferric carboxymaltose covering 517 separate patients who have had mainly iron deficiency without anemia. These results are based on extended periods of follow-up of the patients.

\section{Patients}

The patients were referred for consultation because of typical symptoms of iron deficiency [3,4]. I took a careful clinical history with special attention to any history of blood loss to establish an underlying etiology and made a physical examination. Celiac disease, helicobacter pylori infection and intestinal bleeding were ruled out by appropriate laboratory tests. Other causes of the patient's symptoms, such as hypothyroidism and deficiency of vitamin D, B12 or folic acid, were checked, and treated if found. Furthermore, the vitamin B6 concentration was determined if the patient had used oral vitamin B6 supplementation of more than $10 \mathrm{mg} /$ day for more than six months [10]. If high concentrations were detected, cessation of vitamin B6intake took place.

None of the patients had a history of chronic blood loss. Initially, the iron status was determined by assessment of serum ferritin. If the ferritin concentration was below $100 \mu \mathrm{g} / \mathrm{L}$ or the ferritin concentration was $100-299 \mu \mathrm{g} / \mathrm{L}$ together with a transferrin saturation below $20 \%$ or a low hepcidin concentration (less than half of the lower end of the reference range before the first iron infusion [11,12], the patient was considered iron deficient, regardless of the blood hemoglobin concentration.

The patients were considered suitable for intravenous iron if they had iron deficiency with or without anemia and/or intractable symptoms, if oral iron had not been effective or if they were intolerant to oral iron, were seeking help for infertility or scheduled for in vitro fertilization. All patients were given oral and/or written information about intravenous iron.

All patients received ferric carboxymaltose intravenously in a full-service outpatient practice. The infusion was always initiated and surveyed by the author and at least by one assisting nurse. There was readiness to treat all potential adverse events and get immediate assistance from other health care professionals. The 1000 infusions were given between January 2015 and February 2020. Pregnant patients are excluded from the analysis.

${ }^{\star}$ Correspondence to: Esa Soppi, Department of Internal medicine, Eira Hospital Laivurinkatu 29, FI-00150 Helsinki, Finland, E-mail: esa.soppi@mitconsulting.fi

Key words: iron deficiency, anemia, symptoms, iron infusion, therapy

Received: October 24, 2020; Accepted: October 30, 2020; Published: November 06,2020 
The blood count and serum ferritin concentration as well as the clinical response were scheduled to be checked 6-7 weeks after each infusion which were the main outcome criteria. Ferritin concentration $<100 \mu \mathrm{g} / \mathrm{L}$ at the first or later (2-4 month intervals during the first year) check-ups was considered predictive of poor clinical outcome. The occurrence of hypophosphatemia was not systematically sought. Phosphorous was randomly checked from patients who got $1000 \mathrm{mg}$ doses of iv iron. One patient with asymptomatic hypophosphatemia $(0.49 \mathrm{mmol} / \mathrm{L})$ was detected. The clinical response was scored in a fourpoint scale from 0 (No response) to 3 (Complete or nearly complete relief of clinical symptoms). Follow-up ranged from 2 months to 5 years (median 1.5 years).

All information was collected during standard care and follow-up and there were no additional contacts or laboratory samples and thus ethical approval was not needed.

\section{Results}

The characteristics of the patients are presented in Table 1 . The 1000 infusion covered 517 different individuals out of whom $96 \%$ were females. The dose of $83.4 \%$ of the infusions was $500 \mathrm{mg}$, of $14.7 \%$ it was $1000 \mathrm{mg}$ and in $1.9 \%$ of the cases some other dose was given. Out of the
517 patients 44 did not return for clinical or laboratory controls. $37.3 \%$ of the individuals received only one infusion. The rest of the patients received 2 or more infusions (Table 2). The median interval between infusions ranged from 5.1 to 8.5 months (Table 3 ). The first control after each infusion took place usually after 6-8 weeks.

Infusion-related adverse events occurred in $0.97 \%$ (5 out of 517) of the individuals. All adverse events were rather mild and none of the patients required hospitalization (Table 4). In most cases the infusion was terminated after the adverse event occurred. All infusion reactions occurred during the first infusion. No late infusion reactions (after the iron infusion was completed) were detected.

The mean ferritin concentrations before and after the first infusion were 41.5 and $138.7 \mu \mathrm{g} / \mathrm{L}$, respectively (Table 5 ). Both values were higher during the subsequent infusions but the ferritin increase per 100 $\mathrm{mg}$ of infused iron was still about the same (Table 5). In a few patients the ferritin concentration at the check-up control was lower than the initial ferritin. All of these patients needed further infusion(s) even if their initial clinical response may have been excellent.

The clinical response was not dependent on the achieved increase in ferritin concentration (per $100 \mathrm{mg}$ iron infused) (Figure 1).

Table 1. Gender and age distribution of patients who got iron infusions

\begin{tabular}{|c|c|c|c|c|}
\hline Gender & Infusions given & Different individuals & $\begin{array}{c}\text { Mean age } \\
\text { (yrs) }\end{array}$ & $\begin{array}{c}\text { Age range } \\
\text { (yrs) }\end{array}$ \\
\hline Female & 964 & 497 & 38.5 \\
\hline Male & 36 & 20 & $14-87$ \\
\hline All & 1000 & 517 & 39.9 \\
\hline
\end{tabular}

Table 2. Number of infusions given

\begin{tabular}{|c|c|c|}
\hline Number of infusions & Patients & \\
\hline 1 & 193 & 37.3 \\
\hline $2-4$ & 303 & 58.6 \\
\hline$\geq 5$ & 21 & 4.1 \\
\hline All & $\mathbf{5 1 7}$ & \\
\hline
\end{tabular}

Table 3. Intervals between the infusions

\begin{tabular}{|c|c|c|}
\hline Infusion number & Median interval (months) & Range (months) \\
\hline 1 to 2 & 5.1 & $1.2-51.1$ \\
\hline 2 to 3 & 6.2 & $1.2-28.7$ \\
\hline 3 to 4 & 5.9 & $1.2-31.3$ \\
\hline 4 to 5 & 8.5 & $1.2-36.2$ \\
\hline
\end{tabular}

Table 4. Infusion-related adverse events

\begin{tabular}{|c|c|c|c|c|c|}
\hline $\begin{array}{l}\text { Patient/ } \\
\text { Gender } \\
\text { (age, yrs) }\end{array}$ & Adverse event & $\begin{array}{l}\text { Amount of infused iron } \\
\text { (mg) }\end{array}$ & Actions & Recovery (min) & Interpretation \\
\hline Patient 1/F (29) & $\begin{array}{c}\text { Tightness of the throat and } \\
\text { urticaria }\end{array}$ & $<20$ & Infusion terminated & $\sim 10-15$ & True allergic reaction \\
\hline Patient 2/F (21) & Fever and itching of the skin & $\sim 250$ & Infusion terminated & $\sim 10-15$ & Non-allergic reaction \\
\hline Patient 3/F (32) & $\begin{array}{l}\text { Pressing sensation in the } \\
\text { chest }\end{array}$ & $\sim 350$ & $\begin{array}{l}\text { Infusion temporarily } \\
\text { interrupted for } 15 \mathrm{~min} \text { and } \\
\text { then continued up to } 500 \mathrm{mg}\end{array}$ & $<5$ & Non-allergic reaction \\
\hline Patient 4/F (31) & $\begin{array}{c}\text { Pressing sensation in the } \\
\text { chest, blood pressure increase }\end{array}$ & $<20$ & $\begin{array}{c}\text { Infusion temporarily } \\
\text { interrupted for } 15 \text { min } \\
\text { and then continued with } \\
\text { same symptoms recurring } \\
\text { immediately and infusion } \\
\text { terminated }\end{array}$ & $\sim 10-15$ & Probable allergic reaction \\
\hline Patient $5 * / F(45)$ & $\begin{array}{l}\text { Tightness of the throat and } \\
\text { pressing sensation in the chest }\end{array}$ & 500 & At the end of the infusion & $\sim 30$ & Probable allergic reaction \\
\hline
\end{tabular}

*The patient had severe iron deficiency without anemia (ferritin $<10 \mu \mathrm{g} / \mathrm{L}$ ) with severe symptoms and therefore the patient was rechallenged 8 weeks later. Similar symptoms appeared in the beginning of the $2^{\text {nd }}$ infusion (below $20 \mathrm{mg}$ of iron infused) and the infusion was terminated. 
After the first infusion, $36.8 \%$ of the patients became completely or nearly completely symptomless (Table 6). Even if the response after the 1st infusion was good, about one third these good responders needed at least one additional infusion. Overall, close to $80 \%$ of the patients improved markedly (response categories 2 and 3 ), but about $5 \%$ of the patients experienced no symptom improvement.

\section{Case reports}

Case 1. A 48-year-old female (body mass index $22.0 \mathrm{~kg} / \mathrm{m}^{2}$ ) experienced tiredness and restless legs which had developed during the last three months. She had increasing breathlessness which at the time of consultation was so severe that she could not talk when walking. The blood count $(\mathrm{Hb} 141 \mathrm{~g} / \mathrm{L})$ had been normal and the ferritin had been 36 $\mu \mathrm{g} / \mathrm{L}$ just before consultation.
The patient had tested positive for TPO antibody 30 years ago but the thyroid values had been within the normal range ever since. The patient had used a hormonal IUD for the last 15 years, before which her menstruation had been normal. Now they were minimal. She had delivered one child 18 years earlier and the pregnancy and delivery had been uneventful. She had never donated blood.

Her clinical status was normal with no pallor of the skin or mucous membranes and her blood pressure was 105/65 mmHg. Tests for celiac disease, helicobacter pylori, occult blood in stools, active B12 vitamin, calcium, vitamin D and liver, kidney and thyroid function were normal.

Based on her symptoms and ferritin value, she was considered iron deficient without anemia but the reason for the iron deficiency remained obscure. Because of the severity of the symptoms, iron

Table 5. Ferritin response after infusions of ferric carboxymaltose

\begin{tabular}{|c|c|c|c|}
\hline Infusion & $\begin{array}{c}\text { Mean ferritin }(\mu \mathrm{g} / \mathrm{L}) \text { before infusion } \\
\text { (range) }\end{array}$ & $\begin{array}{c}\text { Mean ferritin }(\mu \mathrm{g} / \mathrm{L}) \text { after infusion } \\
(\text { range) }\end{array}$ & $\begin{array}{c}\text { Mean increase of ferritin }(\mu \mathrm{g} / \mathrm{L}) \text { per } 100 \mathrm{mg} \text { of infused ferric } \\
\text { carboxymaltose } \\
\text { (range) }\end{array}$ \\
\hline $1^{\text {st }}$ infusion & $\begin{array}{c}41.5 \\
(2-249)\end{array}$ & $\begin{array}{c}138.7 \\
(7-542)\end{array}$ & $\begin{array}{c}19.6 \\
(-1.8-58.4)\end{array}$ \\
\hline All infusions & $\begin{array}{c}56.6 \\
(2-305)\end{array}$ & $\begin{array}{c}173.2 \\
(7-662)\end{array}$ & $\begin{array}{c}21.0 \\
(-5.6-61.4)\end{array}$ \\
\hline $1^{\text {st }}$ infusion excluded & $\begin{array}{c}82.1 \\
(2-305)\end{array}$ & $\begin{array}{c}197.0 \\
(22-662)\end{array}$ & $\begin{array}{c}21.5 \\
(-5.6-61.4)\end{array}$ \\
\hline
\end{tabular}

Table 6. Clinical response to intravenous ferric carboxymaltose

\begin{tabular}{|c|c|c|c|}
\hline \multirow{2}{*}{ Description of global clinical response } & After $1^{\text {st }}$ infusion* & Only one infusion & Overall* \\
\hline & \multicolumn{3}{|c|}{ Share of patients (\%) } \\
\hline $\begin{array}{l}\text { Excellent response (3): } \\
\text { Patient completely or nearly completely symptomless }\end{array}$ & 36.8 & 43.7 & 51.8 \\
\hline $\begin{array}{l}\text { Good response (2): } \\
\text { Some symptoms had disappeared, overall situation clearly improved }\end{array}$ & 33.1 & 31.1 & 27.2 \\
\hline $\begin{array}{l}\text { Moderate response (1): } \\
\text { Some relief of part of the symptoms }\end{array}$ & 24.4 & 19.8 & 17.5 \\
\hline No response $(0)$ & 5.7 & 5.4 & 3.5 \\
\hline
\end{tabular}

No response (0)

5.7

67)

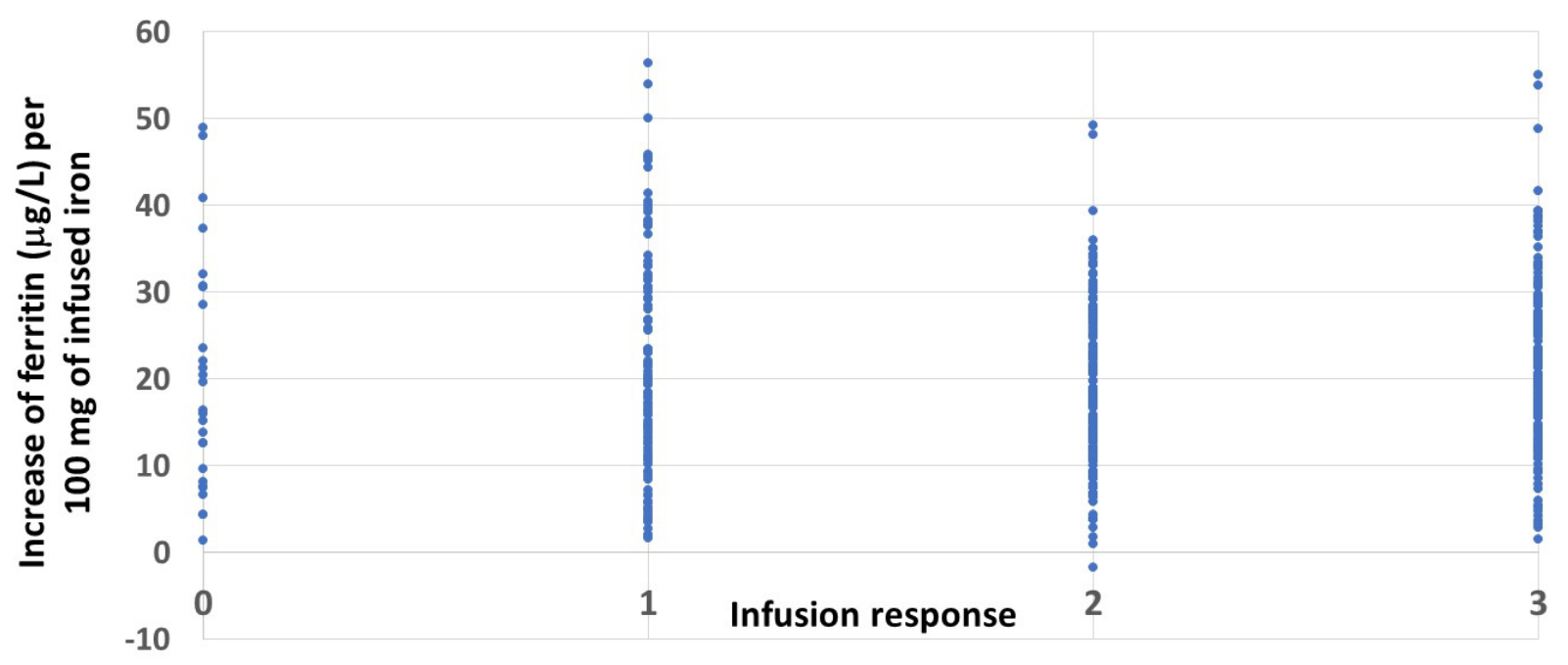

Figure 1. The relationship between increase in ferritin after the first infusion and clinical responses 
infusion was scheduled, and the patient was given $600 \mathrm{mg}$ ferric carboxymaltose. Six weeks after the infusion the patient was feeling well and was symptomless. The ferritin was now $190 \mu \mathrm{g} / \mathrm{L}$ (Figure 2). There was no change in her hemoglobin after the infusion and during followup. During 4 years of follow-up, the patient has remained symptom free although the ferritin concentration has gradually decreased.

Case 2. A female aged 45 years (body mass index $33.2 \mathrm{~kg} / \mathrm{m}^{2}$ ) attended because of anemia. She had type 2 diabetes and took vitamin $\mathrm{D}$ and $\mathrm{B} 12$. She had not tolerated ferrous iron but did take using ferric iron (100 mg twice daily orally) without any effect. Already two years earlier the patient's ferritin had been $3 \mu \mathrm{g} / \mathrm{L}$ and hemoglobin $121 \mathrm{~g} / \mathrm{L}$ with microcytosis and hypochromia. At that time both gastroscopy and colonoscopy had been normal.

She had experienced fatigue, brain fog and restless legs for years, but during the last 12 months her condition had deteriorated and at referral she could no longer manage to climb stairs. She had always had profuse menstruation which had exacerbated after she had stopped contraceptive pills 10 years earlier. She had never donated blood nor been pregnant.

At referral, her hemoglobin was $95 \mathrm{~g} / \mathrm{L}$ with severe microcytosis and hypochromia. Tranexamic acid was prescribed with minimal effects. Because of the severe symptoms and anemia, iron infusion was scheduled, and the patient was given $1000 \mathrm{mg}$ ferric carboxymaltose. This dose increased the hemoglobin concentration considerably but the ferritin only slightly (Figure 3) and her clinical symptoms improved only slightly. The next infusion $(500 \mathrm{mg}$ ) further increased the hemoglobin to the level patient's intrinsic value. But still the increase in ferritin was modest and her physical performance improved only slightly.

A repeat iron infusion $(500 \mathrm{mg}$ ) was given. Now the ferritin increased to $133 \mu \mathrm{g} / \mathrm{L}$ but still her symptoms did not resolve. At this point - because of the continued heavy menstrual bleeding - hysterectomy was performed. The ferritin dropped to $90 \mu \mathrm{g} / \mathrm{L}$ and a fourth infusion $(500 \mathrm{mg}$ ) was given. Now the ferritin increased to $222 \mu \mathrm{g} / \mathrm{L}$ and all of the patient's symptoms disappeared (Figure 3). Thereafter during the follow up the ferritin concentration decreased but the patient remained symptom free. Then the patient was lost from the follow up. Clinical response is presented on the top of the figure according to Table 6.
Case 3. A 38-year-old female (body mass index $18.8 \mathrm{~kg} / \mathrm{m}^{2}$ ) was examined by an occupational health physician because of fatigue, inability to concentrate, reduced recovery from exertion and sleep problems. Her hemoglobin was $126 \mathrm{~g} / \mathrm{L}, \mathrm{E}-\mathrm{MCV}$ was $80 \mathrm{fl}, \mathrm{E}-\mathrm{MCH}$ $26 \mathrm{pg}$ and the platelet count was $160 \times 10^{9} / \mathrm{L}$. The patient had delivered two children and after the second delivery a copper IUD was inserted after which the menstruations had been very abundant. The IUD had been removed just before the consultation. Tests for celiac and thyroid disease were negative and serum ferritin was $9 \mu \mathrm{g} / \mathrm{L}$. Oral iron was prescribed but the patient barely tolerated $100 \mathrm{mg} /$ day. During five months the ferritin increased to $28 \mu \mathrm{g} / \mathrm{L}$ and the hemoglobin to 143 $\mathrm{g} / \mathrm{L}$, but no relief of symptoms took place. A hormonal IUD was tried but not tolerated. Then the patient was referred because iron caused intolerable stomach pain.

The patient was infused with $500 \mathrm{mg}$ ferric carboxymaltose and the patient's symptoms abated considerably (Figure 4) and after a second infusion she became completely free of symptoms. The patient's menstruation remained somewhat abundant and during the followup the ferritin decreased to below $100 \mu \mathrm{g} / \mathrm{L}$ and same symptoms reappeared. The patient got a third infusion of iron. Thereafter she remained practically symptom-free for the next 16 months and the ferritin started to level off at $70 \mu \mathrm{g} / \mathrm{L}$. The effect of three infusions of 500 $\mathrm{mg}$ of ferric carboxymaltose (red arrows) is shown. Clinical response is presented on the top of the figure according to Table 6 .

\section{Discussion}

Ferric carboxymaltose infusions are a safe and effective way of reconstituting depleted iron stores. In this report, only about $1 \%$ of patients had adverse events that resulted in cessation of the infusion $[8,9]$. No high dose infusion schemes were used because most patients had iron deficiency without anemia, where a moderate dose of 500 $\mathrm{mg}$ of ferric carboxymaltose is sufficient. For practical reasons, no formula was used to calculate to required iron dose to replete the iron stores [11], but the patients were rather infused with a standard dose of $500 \mathrm{mg}$ with the expectation that more infusion(s) would be administered if required [11]; this avoided the risk of overtreatment [1] and hypophosphatemia $[13,14]$. Two thirds of the patients required more than one infusion due to decrease of ferritin concentration during

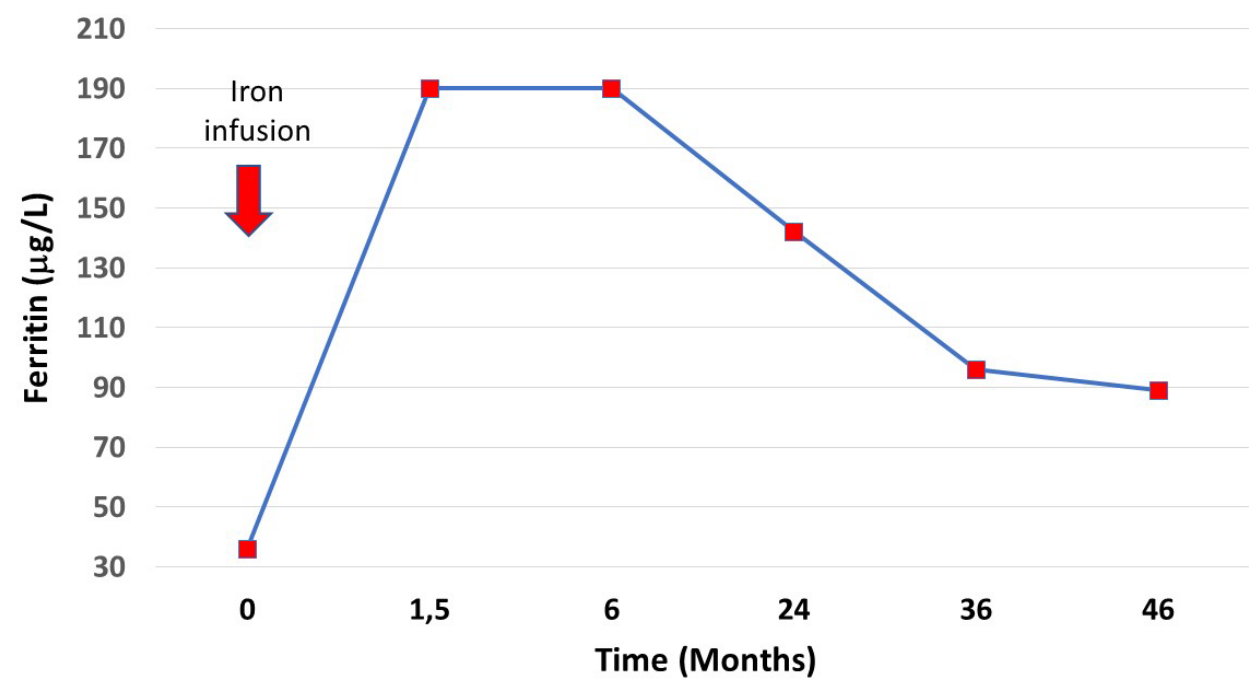

Figure 2. Ferritin concentrations after infusion of ferric carboxymaltose (red arrow/600 mg) and during follow-up 


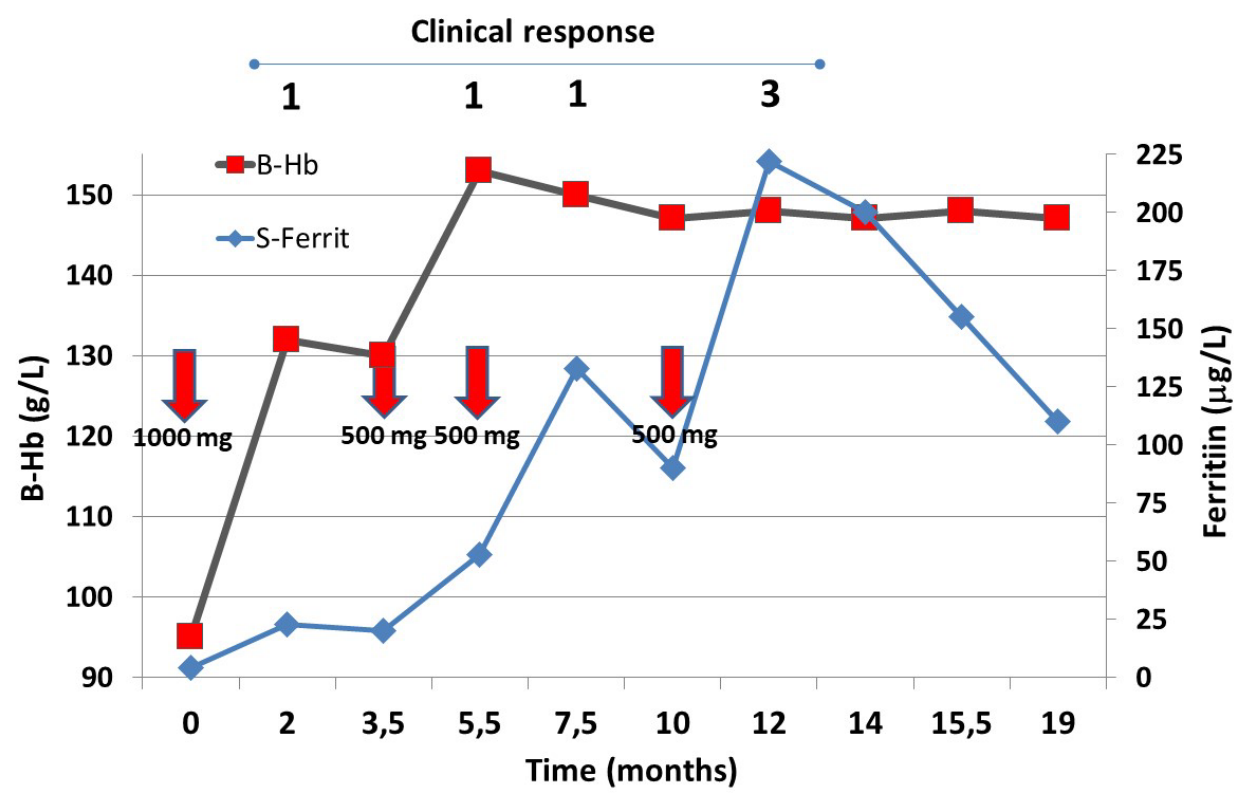

Figure 3. The behavior of hemoglobin and ferritin concentrations after iron infusions (red arrows) during the follow-up

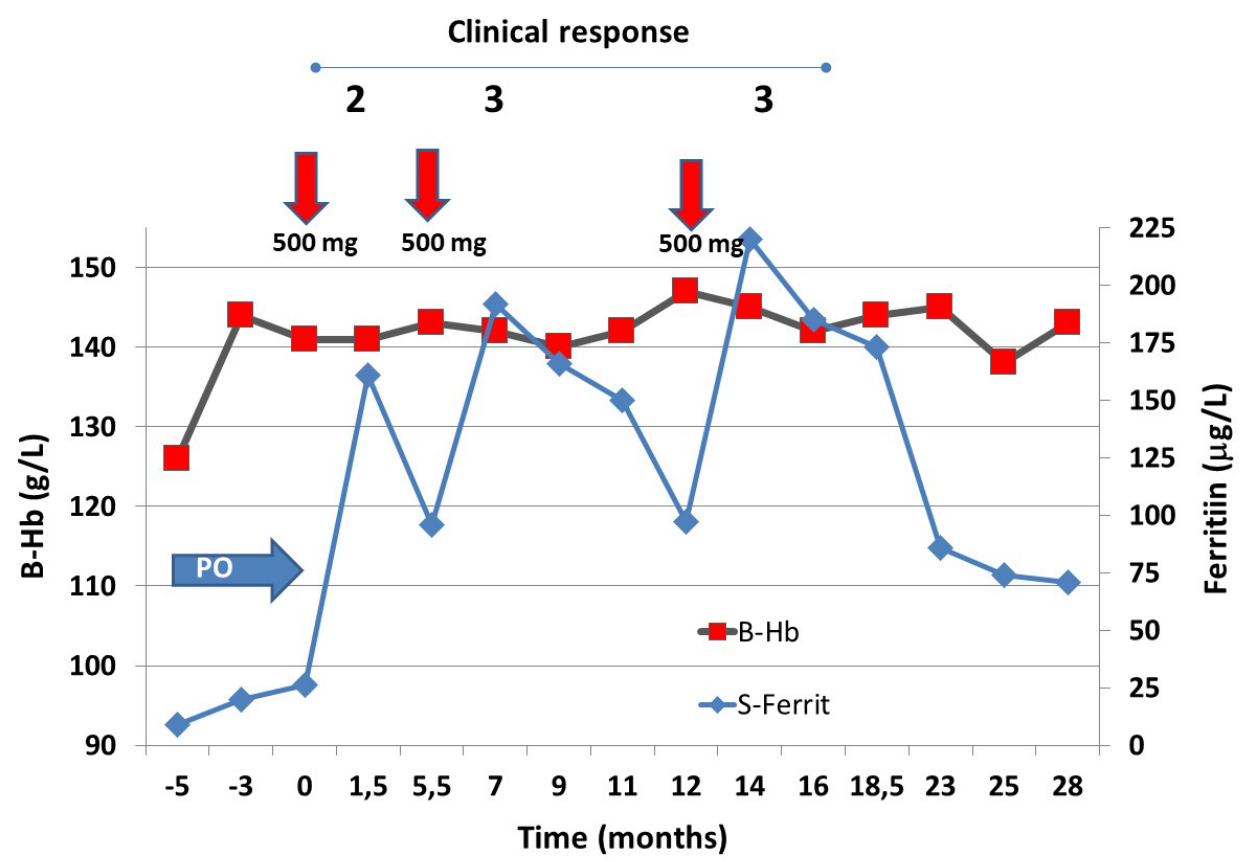

Figure 4. Initially the patient tolerated a short course of oral iron (blue arrow, OI), which normalized the patient's hemoglobin

follow-up and persistence or relapse of symptoms. The median interval between infusions was half a year, but the range stretched from only 6 weeks to several years [10, case reports]. Very little is known about the need for repeated infusions when patients do not have chronic blood loss [10, case reports]. The need for repeated infusions is, of course, partly dependent on the loss of blood with menstrual bleedings, but the main reasons for the decrease in ferritin is related to increased iron utilization especially in muscles and to metabolic processes dependent on iron [15]. The median interval was the same as has been described for the restless leg syndrome at symptoms relapse [15].
The mean increase of ferritin per $100 \mathrm{mg}$ infused iron was about same in each infusion, but symptom relief was not at all dependent on the mean increase of ferritin concentration (Figure 1); individual variation was large. This supports the idea that rapid repletion of iron stores (ferritin concentration $>100 \mu \mathrm{g} / \mathrm{L}$ ) is not enough for symptom relief $[16,17]$ but that repletion of iron in enzyme systems is also needed $[18,19]$. This may take longer periods of time since gene activation induced by iron may be needed to restore the amount and function of proteins of iron dependent metabolic pathways [20,21]. This may explain the results presented in a systematic review on the efficacy of iron supplementation in iron-deficient, nonanemic subjects, which 
concluded that iron treatment (any type) increases $\mathrm{Hb}$ and ferritin and reduces self-reported fatigue but does not improve physical performance or maximal oxygen consumption [22]. In all trials included in the review the time of treatment with iron and follow-up were very short.

Two thirds of the patients in the current study received more than one infusion of iron over the median follow-up of 1.5 years. During this time more than three quarters of the patients improved significantly (Table 6), which shows that extended follow-up is needed if the real effects of iron repletion are to be seen. A clinical impression emerged during the follow-up that the longer the duration of the iron deficiency (especially if the duration based on history was more than 15-20 years), the worse the outcome.

\section{Conclusion}

Ferric carboxymaltose infusions are safe and a clinically effective way of reconstituting depleted iron stores, also in patients with iron deficiency without anemia. It does not seem to be possible to predict the clinical response nor the need for additional infusion(s). Some $60 \%$ of the patients need more than one infusion. Thus, patients who need iron infusion therapy must be followed-up for extended periods of time.

\section{Limitations of the study}

The study population was somewhat heterogenous and the shortest follow-up was only about two months. This is, however, compensated by the large number of patients who were followed-up for extended periods of time and it is foreseeable that those with short follow-up will follow the same clinical course as those with longer follow-up times, which increases the reliability of the study results. In this report, comprehensive iron balance measurements were not available, since the findings were during regular clinical follow-up of the patients. There was no formal symptom scoring system, but I made a global assessment of the treatment response at the first control after each infusion.

\section{References}

1. Camaschella C (2019) Iron deficiency. Blood 133: 30-39.

2. Dallman, PR, Beutler E, Finch CA (1978) Effects of iron deficiency exclusive of anaemia. Br J Haematol 40: 179-184. [Crossref]

3. Goodnough LT, Nemet E (2018) Iron deficiency and related disorders. Greer JP, Arber DA, Glader BE, List AF, Means RT, Rodgers GM (eds). In Wintrobe's Clinical Hematology, $14^{\text {th }}$ edition. Wolters Kluwer Health 615-43.

4. Soppi E (2019) Iron deficiency without anemia - common, important, neglected. CCRR 5: $1-7$.
5. Camaschella C (2017) New insights into iron deficiency and iron deficiency anemia. Blood Rev 31: 225-233. [Crossref]

6. Clénin GE (2017) The treatment of iron deficiency without anaemia (in otherwise healthy persons). Swiss Med Wkly 147: w14434. [Crossref]

7. Tolkien Z, Stecher L, Mander AP, Pereira DI, Powell JJ (2015) Ferrous sulfate supplementation causes significant gastrointestinal side effects in adults: a systematic review and meta-analysis. PLoS One 10: e0117383. [Crossref]

8. Auerbach M, Macdougall IC (2014) Safety of intravenous iron formulations: Facts and folklore. Blood Transfus 12: 296-300. [Crossref]

9. Gómez-Ramírez S, Shander A, Spahn DR, Auerbach M, Liumbruno GM, et al. (2019) Prevention and management of acute reactions to intravenous iron in surgical patients. Blood Transfus 17: 137-45. [Crossref]

10. Soppi E (2018) Iron deficiency without anaemia - a clinical challenge. Clin Case Rep 6: 1082-1086. [Crossref]

11. Anker SD, Comin Colet J, Filippatos G, Willenheimer R, Dickstein K, et al. (2009) Ferric carboxymaltose in patients with heart failure and iron deficiency. $N$ Engl J Med 361: 2436-2448. [Crossref]

12. Litton E, Baker S, Erber W, Farmer S, Janet F, et al. (2018) Hepcidin predicts response to IV iron therapy in patients admitted to the intensive care unit: a nested cohort study. $J$ Intensive Care 6: 60-66. [Crossref]

13. Schaefer B, Philipp Würtinger P, Finkenstedt A, Vickie B, André V, et al. (2016) Choice of high-dose intravenous iron preparation determines hypophosphatemia risk. PLoSOne 11: 1-11. [Crossref]

14. Wolf M, Chertow GM, Macdougall IC, Kaper R, Krop J, et al. (2018) Randomized trial of intravenous iron-induced hypophosphatemia. JCI Insight 3: 3-15. [Crossref]

15. Earley CJ, Heckler D, Allen RP (2005) Repeated IV doses of iron provides effective supplemental treatment of restless legs syndrome. Sleep Med 6: 301-305. [Crossref]

16. Harju E, Pakarinen A, Larmi TA (1984) A comparison between serum ferritin concentration and the amount of bone marrow stainable iron. Scand J Clin Lab Invest 44: 555-556. [Crossref]

17. Mast AE, Blinder MA, Gronowski AM, Chumley C, Scott MG (1998) Clinical utility of the soluble transferrin receptor and comparison with serum ferritin in several populations. Clin Chem 44: 45-51. [Crossref]

18. Lawen A, Lane DJR (2013) Mammalian iron homeostasis in health and disease: Uptake, storage, transport, and molecular mechanisms of action. Antioxid Redox Signal 18: 2473-2507. [Crossref]

19. Rouault TA, Maio N (2017) Biogenesis and functions of mammalian iron-sulfur proteins in the regulation of iron homeostasis and pivotal metabolic pathways. $J$ Biol Chem 92: 12744 -12753. [Crossref]

20. Oexle H, Gnaiger E, Weiss G (1999) Iron-dependent changes in cellular energy metabolism: Influence on citric acid cycle and oxidative phosphorylation. Biochimica et Biophysica Acta 1413: 99-107.

21. Kaplan J, McVey Ward D, Crisp RJ, Philpot CC (2006) Iron-dependent metabolic remodeling in S. cerevisiae. Biochimica et Biophysica Acta 1763: 646-651. [Crossref]

22. Houston BL, Hurrie D, Graham J, Brittany P, Emily R, et al. (2018) Efficacy of iron supplementation on fatigue and physical capacity in non-anaemic iron deficient adults: A systematic review of randomized controlled trials. BMJ Open 8: e019240. [Crossref]

Copyright: (C2020 Soppi E. This is an open-access article distributed under the terms of the Creative Commons Attribution License, which permits unrestricted use, distribution, and reproduction in any medium, provided the original author and source are credited. 